Filip Tereszkiewicz

Politechnika Opolska

DOI: $10.19195 / 2450-274 X .2 .7$

\title{
Rola Unii Europejskiej na arenie międzynarodowej według partii eurosceptycznych - nowy wymiar wspólnoty?
}

Abstrakt: W artykule zostało omówione podejście partii eurosceptycznych, których członkowie zasiadają w Parlamencie Europejskim VIII kadencji, do kwestii polityki zagranicznej, a także ich wizja miejsca Unii w nowym układzie międzynarodowym. Autor prezentuje elementy łączące te ugrupowania (stosunek do USA, Rosji, NATO, imigracji) oraz obszary, które według nich mogłyby nadal być realizowane w ramach ogólnoeuropejskiej współpracy (polityka współpracy rozwojowej, polityka klimatyczna). Na koniec została zaprezentowana wizja „eurosceptycznej tożsamości europejskiej”, która może stanowić podstawę do szukania roli, którą mniej lub bardziej zjednoczona Europa mogłaby odgrywać w nowym ładzie międzynarodowym w przypadku wzrastającego poparcia społecznego dla ugrupowań eurosceptycznych.

Słowa kluczowe: eurosceptycyzm, polityka zagraniczna, Unia Europejska

The role of the European Union in the international arena by the Eurosceptic parties: A new dimension of the community?

Abstract: A Eurosceptical attitude towards EU foreign affairs and an EU position in a new international order is presented in the paper. The author concentrates on Eurosceptic parties whose members are sitting in the European Parliament 8th term. Elements which are common for these politicians are described (the attitude toward US, Russia, NATO and immigration). Activities which, in the opinion of the Eurosceptic MEP, could be conducted in the framework of the European cooperation are identified (development assistance, environmental policy). At the end we are presented with a "Eurosceptical European identity", which could be a basis for the international activity of the more or less integrated Europe.

Keywords: Euroscepticism, foreign policy, European Union 


\section{Wstęp}

Wybory do Parlamentu Europejskiego z maja 2014 r. oraz kolejne elekcje przeprowadzane w państwach członkowskich bardzo wyraźnie pokazały wzrastające poparcie dla partii radykalnych, w tym tych o charakterze eurosceptycznym. Dlatego też zasadne staje się pytanie o to, czy tytułowe środowiska łączy wspólna wizja przyszłości kontynentu i czy znajduje się w niej miejsce dla jakiegoś wymiaru współpracy ogólnoeuropejskiej, np. w ramach Unii Europejskiej. W prezentowanym artykule autor próbuje odpowiedzieć na to pytanie, biorąc pod uwagę obszar polityki zagranicznej i koncentrując się przede wszystkim na partiach, których członkowie znaleźli się w Parlamencie Europejskim VIII kadencji. Poprzez analizę wystąpień w czasie debat, programów wyborczych oraz wpisów na portalach społecznościowych stara się opisać pewne elementy wspólne łączące omawiane środowisko polityczne i zdefiniować wizję tego, jak eurosceptycy wyobrażają sobie miejsce zintegrowanej Europy na arenie międzynarodowej. Jest to ważna kwestia, ponieważ obecnie znajdujemy się w okresie transformacji globalnego układu sił. Niemal powszechne jest przekonanie, że nowy ład międzynarodowy będzie miał multilateralny charakter bez jednoznacznych biegunów. Unia będzie zatem musiała spróbować na nowo zdefiniować siebie w kontekście przyszłego układu sił. Głos partii eurosceptycznych jest niezwykle istotny, gdyż można zaobserwować wzrastające poparcie społeczne dla tego środowiska, co może skłonić partie głównego nurtu do przejęcia części jego programu. Warto więc dowiedzieć się, jaki (jeśli w ogóle) wymiar wspólnoty europejskiej marzy się eurosceptykom — dzięki temu będzie można bowiem przewidzieć i zrozumieć zmiany zachodzące w polityce zagranicznej państw członkowskich i Unii.

\section{Partie eurosceptyczne a działania zewnętrzne Unii Europejskiej}

Przystępując do analizy podejścia partii eurosceptycznych do kwestii roli, jaką Europa ma odgrywać na arenie międzynarodowej, trzeba przede wszystkim podkreślić, że w doktrynie toczy się dyskusja nad samym pojęciem eurosceptycyzmu i tego, czym on jest ${ }^{1}$. Zasadniczy spór dotyczy jego esencji, czyli tego, jaki jest stosunek tego nurtu politycznego do Unii Europejskiej. Niejednoznaczność po-

${ }^{1}$ Zob. K. Zuba, Polski eurosceptycyzm i eurorealizm, Opole 2006, s. 17-67; C. Sørensen, Love me, love me not... A typology of public Euroscepticism, „SEI Working Paper” 2008, nr 101, s. 1-19; S. Vasilopolou, Varieties of Euroscepticism: The Case of the European Extreme Right, „Journal of Contemporary European Research" 5, 2009, nr 1, s. 3-23; A. Moroska, Prawicowy populizm i eurosceptycyzm (na przykładzie Listy Pima Fortuyna w Holandii i Ligii Polskich Rodzin w Polsce), Wrocław 2010, s. 56-68; C. Leconte, From pathology to mainstream phenomenon: Reviewing the Euroscepticism debate in research and theory, „International Political Science Review” 2015, 36, s. 250-263. 
glądów politycznych sprawia, że w literaturze upowszechnił się podział na twardy eurosceptycyzm, którego celem jest rozwiązanie Unii Europejskiej, i miękki eurosceptycyzm, stawiający sobie za zadanie ograniczenie roli UE, najlepiej do strefy wolnego handlu ${ }^{2}$. Jednak zasadniczym problemem podejmowanym $\mathrm{w}$ niniejszej pracy jest to, że zdecydowana większość partii eurosceptycznych koncentruje się w swoich programach na kwestiach wewnętrznych, traktując marginalnie problematykę międzynarodową, $\mathrm{z}$ wyjątkiem sytuacji, gdy ma ona istotne znaczenie dla obywateli danego państwa ${ }^{3} . \mathrm{Z}$ powodu tego désintéressement ugrupowania reprezentujące twardy eurosceptycyzm - negujące przecież sens istnienia Unii - dopuszczają pewne formy współpracy w ramach zjednoczonej Europy w obszarze działań zewnętrznych ${ }^{4}$. Uprawniona wydaje się też teza, że partie te wraz ze wzrastającym poparciem oraz znaczeniem w polityce krajowej i europejskiej będą zmuszone redefiniować odgrywaną przez siebie rolę i zwiększyć swoje zainteresowanie problematyką międzynarodową. Potwierdzeniem tego jest fakt, iż ugrupowania zyskujące na znaczeniu na krajowej scenie politycznej w coraz większym stopniu włączają kwestie międzynarodowe do swoich programów politycznych ${ }^{5}$. Niemniej jednak można zaobserwować, że partie eurosceptyczne bardzo często są w omawianej kwestii niespójne, nie tylko między sobą, lecz także wewnętrznie. Wynika to po części z ich struktury, która nawet w partiach wodzowskich nie jest do końca hierarchiczna, a przez to narzucająca poglądy w mało istotnych z punktu widzenia elektoratu lub lidera kwestiach. Ponadto niespójność ta może mieć swoje źródła w logice stosowności nakazującej im dostosowywać się do poglądów dominujących w społeczeństwach państw, z których pochodzą.

W niniejszej pracy zostały uwzględnione partie polityczne, których członkowie uzyskali mandat Parlamentu Europejskiego VIII kadencji i albo przystąpili do jednej z dwóch frakcji reprezentujących twardy eurosceptycyzm (Europa Wolności i Demokracji Bezpośredniej oraz Europa Narodów i Wolności), albo też pozostali niezrzeszeni ${ }^{6}$. Pierwsza ze wspomnianych grup politycznych łączy w sobie pochodzący z Włoch ekologiczno-populistyczny Ruch 5 gwiazdek (Movimento

2 A. Szczerbiak, P. Taggart, Theorising party-Based based Euroscepticism: Problems of Definitiondefinition, Measurement measurement and Causalitycausality, "SEI Working Paper" 2003, nr 69, s. 6; A. Moroska, op. cit., s. 57-78.

${ }^{3}$ Y. Ben-Hur Levy, The Undiplomats: Right-wing populist and their foreign policies, 2015, s. 5, http://www.cer.org.uk/sites/default/files/publications/attachments/pdf/2015/pb_ybl_undiplo_21aug15-11804.pdf (dostęp: 12 grudnia 2015).

${ }^{4}$ Zob. F. Tereszkiewicz, Unia Eurosceptyków - implikacje dla działań zewnętrznych Unii Europejskiej, [w:] Integracja europejska. Główne obszary badawcze, red. K.A. Wojtaszczyk, J. Tymanowski, P. Stawarz, Warszawa 2015, s. 487-498.

${ }^{5}$ Bardzo dobrze proces ten widać na przykładzie francuskiego Frontu Narodowego oraz brytyjskiego UKIP. Zob. Y. Ben-Hur Levy, op. cit., s. 5-8.

${ }^{6}$ Grupa polityczna Europejskich Konserwatystów i Reformatorów nie została uwzględniona $\mathrm{z}$ racji tego, że nie reprezentuje ona twardego eurosceptycyzmu, tj. jej celem jest jedynie redefiniowanie współpracy w ramach Unii Europejskiej, a nie jej likwidacja. Zob. Deklaracja praska, http://www.ecrg.pl/pl/o_nas/ (dostęp: 26 kwietnia 2016). 
5 Stelle $)^{7}$ i takie partie skrajnie prawicowe, jak: brytyjska Partia Niepodległości Zjednoczonego Królestwa (United Kingdom Independence Party - UKIP), litewska Partia Porządek i Sprawiedliwość (Partija Tvarka ir teisingumas), Szwedzcy Demokraci (Sverigedemokraterna), czeska Partia Wolnych Obywateli (Strana svobodných občanů), a także polskiego deputowanego z KORWiN (Roberta Iwaszkiewicza) oraz wykluczoną $z$ francuskiego Frontu Narodowego Joëlle Bergeron ${ }^{8}$. Natomiast ukształtowana rok po rozpoczęciu kadencji przez Parlament Europejski Europa Narodów i Wolności składa się niemal w całości ze środowisk należących do skrajnie prawicowej europartii Europejski Sojusz na rzecz Wolności, tj. francuskiego Frontu Narodowego (Front National), włoskiej Ligi Północnej (Lega Nord), Wolnościowej Partii Austrii (Freiheitliche Partei Österreichs - FPÖ), holenderskiej Partii Wolności (Partij voor de Vrijheid), polskiego Kongresu Nowej Prawicy, belgijskiego Interesu Flamandzkiego (Vlaams Belang) oraz wykluczonej z UKIP Janice Atkinson i Rumuna Laurenţiu Rebega9 .

Tak jak to zostało wspomniane już wcześniej, oprócz Europy Wolności i Demokracji Bezpośredniej oraz Europy Narodów i Wolności twardy eurosceptycyzm reprezentują w Parlamencie Europejskim deputowani niezrzeszeni w żadnej grupie politycznej. Nie mają oni większego wpływu na funkcjonowanie unijnej legislatury, jednak znajdują się wśród nich przedstawiciele kilku partii, które odgrywają znaczącą rolę w swoich ojczyznach. Z pewnością trzeba wskazać wśród nich

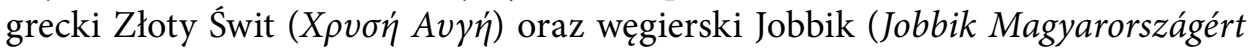
Mozgalom). Obecnie nie mają one realnych szans na współrządzenie, ale stanowią istotne zagrożenie dla partii prawicowych w swoich ojczyznach, co sprawia, że te ostatnie często pozycjonują się w stosunku do ich przekazu.

\section{Miejsce Europy na arenie międzynarodowej w oczach partii eurosceptycznych}

Analizując dokumenty programowe omawianych partii eurosceptycznych oraz wystąpienia ich liderów, można wyróżnić kilka punktów wspólnych (tzw. dyskursywnych punktów węzłowych ${ }^{10}$ ) pozwalających na zdefiniowanie wizji miejsca Europy i Unii na arenie międzynarodowej. Podobieństwa pomiędzy nimi są na tyle istotne, że można stwierdzić, iż ugrupowania te prezentują nową wizję

${ }^{7}$ Ruch 5 gwiazdek reprezentuje raczej miękki eurosceptycyzm, jednak jego członkowie przystąpili do frakcji programowo prezentującej twardą wersję tego nurtu politycznego.

${ }^{8}$ Members, http://www.efdgroup.eu/our-meps/members (dostęp: 21 grudnia 2015).

${ }^{9}$ Grupa Europa Narodów $i$ Wolności, http://www.europarl.europa.eu/meps/pl/search.html? politicalGroup=4907 (dostęp: 21 grudnia 2015).

${ }^{10}$ Więcej na temat dyskursywnych punktów węzłowych T. Diez, The Economic Community Reading of Europe: Its Discursive Nodal Points and Ambiguities Towards „Westphalia”, „Working Papers" 1998, nr 6, s. 3-7; idem, Europe as a Discursive Battleground. Discourse Analysis and European Integration Studies, „Cooperation and Conflict” 2001, nr 1(36), s. 15-24. 
„wspólnoty europejskiej” opartej na całkowicie odmiennym postrzeganiu pozycji zjednoczonej Europy w globalnym układzie sił. Wspólnota ta ma cechy zdefiniowanej przez E. Adera i M. Barnetta wspólnoty bezpieczeństwa, której członkowie dzielą wspólne tożsamości, wartości i pojęcia oraz kierują się w swoich działaniach poczuciem odpowiedzialności za nią ${ }^{11}$.

Analizując eurosceptyczny dyskurs i dostępne założenia programowe, można zauważyć, że większość badanych partii opowiada się za rozluźnieniem więzów z USA ${ }^{12}$. Ich członkowie uważają, że Stany Zjednoczone odgrywają zbyt aktywną rolę na Starym Kontynencie, a państwa europejskie tracą na tym zarówno pod względem ekonomicznym, jak i politycznym. Ugrupowania te niemal powszechnie krytykują ich zdaniem zbyt proamerykańską politykę poszczególnych rządów i nieuwzględnianie przez to specyficznych interesów Europy. Ta krytyka w ostatnim czasie koncentruje się na dwóch obszarach.

Przede wszystkim, partie eurosceptyczne negują w większości sens sankcji nakładanych na Rosję za aneksję Krymu i destabilizację wschodu Ukrainy ${ }^{13}$. Uważają, że jest to wbrew interesom ekonomicznym państw członkowskich, które tracą przez to ogromny rynek zbytu i stabilnego dostawcę surowców energetycznych. Polityka sankcji jest, według nich, w interesie Amerykanów, którzy nie ponosząc żadnych realnych kosztów jej prowadzenia, wypychają Rosję z europejskich rynków i osłabiają możliwości inwestycyjne europejskich przedsiębiorców ${ }^{14}$. Widać więc $\mathrm{w}$ tym przypadku próbę odgrywania przez polityków tych partii roli sprzedawcy norm przez zastosowanie logiki perswazji. Odwołując się do racjonalnych argumentów i interesu państw członkowskich, starają się oni zmodyfikować ton debaty na temat rosyjskiej polityki wobec Ukrainy i tym samym doprowadzić do jej zmiany. Tę „racjonalną" narrację zaburza jednak popularna wśród eurosceptyków opinia, że to Waszyngton, próbując związać Ukrainę z NATO i zainstalować na jej terytorium bazy, sprowokował Kreml do podjęcia działań chroniących tradycyjną strefę wpływów. Część z nich sądzi również, że to Amerykanie celowo wywołali Majdan, a ich siły specjalne bezpośrednio zaangażowane są w walki na wschodzie Ukrainy ${ }^{15}$.

${ }^{11}$ E. Adler, M. Barnett, A Framework for the Study of Security Communities, [w:] Security Communities, red. E. Adler, M. Barnett, Cambridge 1998, s. 31.

${ }^{12}$ Wyjątkiem w tej grupie jest brytyjski UKIP i holenderska Partia Wolności.

${ }^{13} \mathrm{~J}$. Korwin-Mikke w audycji radiowej „Wybierz swojego prezydenta” w radiu TOK FM, https://www.youtube.com/watch? $=$ =F8GTH4G2E2w\&index=15\&list=PLVLI1ArZ-BLZv4sLKp nmH_Ml6cF4AzIW (dostęp: 29 grudnia 2015); Ucraina, ammissioni Biden, Pini (ln): Mogherini mente, sanzioni a Russia pilotate da usa, http://leganord.org/index.php/notizie/le-news/13287-ucraina-ammissioni-biden-pini-ln-mogherini-mente-sanzioni-a-russia-pilotate-da-usa (dostęp: 17 grudnia 2015); G. Annemans, D. Bilde, S. Briois, Stan stosunków UE-Rosja, 10.06.2015, http:// www.europarl.europa.eu/sides/getDoc.do?pubRef=-//EP//TEXT+CRE+20150610+ITEM-00905+DOC+XML+V0//PL\&language=PL (dostęp: 29 grudnia 2015).

${ }_{14}$ Z. Balczó, D. Dodds, G. Epitideios, L. Fontana, B. Kovács, E. Synadinos, Stan stosunków UE-Rosja, 10 czerwca 2015.

${ }^{15}$ J. Ivanauskas, Rolandas Paksas: „Apsimesdami didžiais valstybès gynejjais, kai kurie "patriotai« daro viską, kad būtų išprovokuotas karinis konfliktas su Rusija!”, http://www.laisvaslaikrastis. 
Drugim obszarem krytyki jest negocjowane $\mathrm{z}$ Waszyngtonem transatlantyckie porozumienie $\mathrm{w}$ dziedzinie handlu i inwestycji (Transatlantic Trade and Investment Partnership, TTIP). W tym przypadku również widać zastosowanie logiki perswazji, gdyż większość partii eurosceptycznych używa racjonalnych z punktu widzenia ugrupowań mainstreamowych argumentów, podkreślając, że umowa ta jest istotnym zagrożeniem dla interesów gospodarczych państw członkowskich. Porozumienie o liberalizacji handlu doprowadzi, według nich, do kolejnego kryzysu w Europie. W wypowiedziach przedstawicieli tych partii pojawia się kilka wspólnych zarzutów w stosunku do tej umowy międzynarodowej. Przede wszystkim zwracają oni uwagę, iż jest ona negocjowana w tajemnicy i nie ma kontroli społecznej nad umieszczanymi tam zapisami. Ta tajność negocjacji wskazuje ich zdaniem, że porozumienie będzie prawdopodobnie uderzało w przedsiębiorstwa i społeczeństwa państw członkowskich, a zyski przyniesie wyłącznie międzynarodowym korporacjom ${ }^{16}$. Innym pojawiającym się bardzo często zarzutem jest umieszczenie $\mathrm{w}$ TTIP podstawy prawnej pozwalającej pozywać rządy państw członkowskich za wprowadzenie zmian prawnych i podatkowych ograniczających zyski przedsiębiorstw ${ }^{17}$. Zdaniem eurosceptyków narusza to suwerenność krajów członkowskich i będzie w przyszłości ograniczało możliwości zmiany polityki przez nowe gabinety ${ }^{18}$. Bardzo duże zagrożenie wspomniana umowa niesie, według nich, również dla europejskiego rolnictwa, w tym tego o tradycyjnym charakterze. Zarzuty koncentrują się na dwóch kwestiach — osłabieniu ochronnego charakteru oznaczeń geograficznych ${ }^{19}$ oraz pogorszeniu się standardów jakości żywności ${ }^{20}$. Ostatnim, często pojawiającym się zarzutem w stosunku do TTIP jest to, że przyczyni się ona do wzmocnienia inwigilacji Europejczyków przez amery-

lt/news/2482/53/d,detalus/ (dostęp: 23 grudnia 2015); M. Ciastoch, Korwin-Mikke: To Amerykanie zdestabilizowali Ukraine, http://swiat.newsweek.pl/janusz-korwin-mikke-teorie-spiskowe-ameryka-chce-oslabic-rosje,artykuly,359188,1.html (dostęp: 18 grudnia 2015); H. Vilimsky, Sytuacja na Ukrainie 15 lipca 2014 r., http://www.europarl.europa.eu/sides/getDoc.do?pubRef=-//EP// TEXT+CRE+20140715+ITEM-008+DOC+XML+V0//PL\&language=PL (dostęp: 29 grudnia 2015); Ucraina, ammissioni Biden...; Le Pen says Washington attempting to start 'war in Europe', http:// rt.com/news/230503-le-pen-us-lackey/ (dostęp: 17 grudnia 2015); Vilimsky: Rolle der NATO in der Ukraine bedenklich, http://www.ots.at/presseaussendung/OTS_20150311_OTS0168/vilimsky-rolle-der-nato-in-der-ukraine-bedenklich (dostęp: 17 grudnia 2015).

${ }^{16}$ R. Iwaszkiewicz, Negocjacje $w$ sprawie transatlantyckiego partnerstwa handlowo-inwestycyjnego (TTIP), 9.07.2015, http://www.europarl.europa.eu/sides/getDoc.do?pubRef=-//EP// TEXT+CRE+20150709+ITEM-013-01+DOC+XML+V0//PL\&language=PL(dostęp:29 grudnia2015).

${ }^{17}$ Z. Balczó, G. Buonanno, Negocjacje...

${ }_{18}$ Z. Balczó, Transatlantyckie Partnerstwo $w$ dziedzinie Handlu i Inwestycji (TTIP), 15.07.2014, http://www.europarl.europa.eu/portal/pl, http://www.europarl.europa.eu/sides/getDoc.do?pubRef=-//EP//TEXT+CRE+20140715+ITEM-009+DOC+XML+V0//PL\&language=PL (dostęp: 12 grudnia 2015); M.-Ch. Arnautu, N. Bay, A. Chauprade, R. Iwaszkiewicz, M. Le Pen, Negocjacje...

19 E. Ferrand, Transatlantyckie...; G. Buonanno, Negocjacje...

${ }^{20}$ G. Moi, M. Salvini, Transatlantyckie...; K. Morvai, N. Bay, G. Epitideios, R. Iwaszkiewicz, Negocjacje... 
kańskie służby. Politycy partii eurosceptycznych podkreślają, iż w Unii ochrona prywatności oraz danych osobowych jest dużo bardziej rygorystyczna, a liberalizacja handlu z USA wymusi na europejskich firmach dostosowanie się do rozwiązań amerykańskich ${ }^{21}$.

Wszystkie przytoczone powyżej argumenty sprawiają, że partie eurosceptyczne wzywają do zerwania negocjacji nad TTIP. Jedynie UKIP oraz czescy Wolni Obywatele zajmują niejednoznaczne stanowisko w stosunku do tej umowy. Z jednej strony opowiadają się za utworzeniem pogłębionej strefy wolnego handlu z USA ${ }^{22}$, z drugiej jednak mają istotne wątpliwości dotyczące tego, czy Komisja Europejska jest w stanie wynegocjować dobre dla Unii warunki ${ }^{23}$. Sprawia to, że, w przeciwieństwie do pozostałych partii, nie zajmują one jednoznacznego stanowiska, uzależniając swoją decyzję od ostatecznego kształtu porozumienia ${ }^{24}$.

Drugim filarem spajającym większość partii eurosceptycznych jest przekonanie o konieczności zacieśnienia współpracy z Federacją Rosyjską ${ }^{25}$. Większość tych ugrupowań albo zajmuje zdecydowanie prorosyjskie stanowisko, albo też wykazuje zrozumienie dla polityki prowadzonej przez to państwo. Przede wszystkim politycy eurosceptyczni uważają, iż Moskwa jest w większym stopniu wrażliwa na europejskie interesy niż Waszyngton. Wynika to z tego, że Europę i Rosję łączą silne więzy historyczne i kulturowe oraz podobne interesy geopolityczne ${ }^{26}$. Poza tym politycy tych partii są przekonani - zresztą nie bez racji — iż Rosja jest niezbędna do zakończenia konfliktu w Syrii, a tym samym nie da się bez niej rozwiązać dotykającego obecnie Unię kryzysu uchodźczego ${ }^{27}$. Co jednak istotniejsze, zde-

${ }^{21}$ T. Beghin, Transatlantyckie...; I. Adinolfi, G. Annemans, J. Carver, Negocjacje...

${ }^{22}$ P. Nuttall, UKIP statement on TTIP, 15.10.2015, http://www.paulnuttallmep.com/ukip-statement-on-ttip/ (dostęp: 11 grudnia 2015); P. Mach, Transatlantyckie...; P. Mach, Negocjacje...

${ }^{23}$ F. Bermingham, Rochester By-Election: What's Ukip's Policy on TTIP?, 21.11.2014, http:// www.ibtimes.co.uk/rochester-by-election-whats-ukips-policy-ttip-1475884 (dostęp: 11 lutego 2015); J. Arnott, Negocjacje...

${ }^{24}$ N. Smith, UKIP's Policy on the NHS and TTIP's, 25.01.2015, http://lincolngainsboro.blogspot.com/2015/01/ukips-policy-on-nhs-and-ttips.html (dostęp: 11 grudnia 2015); P. Mach, Transatlantyckie...

${ }^{25}$ Bardzo wyraźnie o tym mówi, np. M. Salvini, Stan stosunków UE-Rosja, 10.06.2015.

${ }^{26}$ PVV, Welk belang heeft de Nederlander bij sancties tegen Rusland?, http://www.pvv.nl/index. php/37-fj-related/raymond-de-roon/7463-pvv-welk-belang-heeft-de-nederlander-bij-sancties-tegen-rusland.html (dostęp: 11 grudnia 2015); Russia-index: 11 new EU-sceptic parties added, https:// eublogg.wordpress.com/2015/01/10/russia-index-11-new-eu-sceptic-parties-added/ (dostęp: 10 grudnia 2015); Macro-financial assistance to Ukraine, http://www.votewatch.eu/en/term8-macro-financial-assistance-to-ukraine-draft-legislative-resolution-vote-legislative-resolution-ordin.html\#/ (dostęp: 10 grudnia 2015); Nya diskussioner om SD:s Putin-relation efter DN:s avslöjande, https:// eublogg.wordpress.com/2015/02/16/nya-diskussioner-om-sds-putin-relation-efter-dns-avslojande/ (dostęp: 10 grudnia 2015); M.-Ch. Arnautu, M. D’Ornano, Stan stosunków UE-Rosja, 10.06.2015...

${ }^{27}$ N. Farage, G. Buonanno, Sytuacja na Ukrainie i stan stosunków UE-Rosja, 16.09.2014, http://www.europarl.europa.eu/sides/getDoc.do?pubRef=-//EP//TEXT+CRE+20140916+ITEM$-004+\mathrm{DOC}+\mathrm{XML}+\mathrm{V0} / / \mathrm{PL} \&$ language $=\mathrm{PL}$ (dostęp: 12 grudnia 2015); J. Carve, F.M. Castaldo, Sytuacja na Ukrainie (debata), 14.10.2015, http://www.europarl.europa.eu/sides/getDoc.do?pubRef=-// 
cydowana większość eurosceptycznych polityków uważa, iż Rosja może pomóc wyjść z recesji państwom członkowskim. Wskazują oni na fakt, że jest ona ogromnym rynkiem zbytu dla unijnych produktów i potencjalnym miejscem inwestycji dla unijnych przedsiębiorców ${ }^{28}$. Politycy ci wskazują również na uzależnienie energetyczne zjednoczonej Europy od Rosji wymuszające ściślejszą współpracę pomiędzy tymi podmiotami ${ }^{29}$. Ponadto wskazują, że lepiej importować surowce z chrześcijańskiej Rosji niż ze zdestabilizowanych - a co gorsza muzułmańskich - krajów Afryki Północnej i Bliskiego Wschodu ${ }^{30}$.

Chociaż widać próbę odwoływania się przez członków tych partii do racjonalnych gospodarczo i politycznie argumentów (logika perswazji), to jednak wyraźnie życzliwe podejście do Rosji, budowane w dużej mierze w opozycji do Stanów Zjednoczonych, ma swoje źródło we wspólnocie ideologicznej. W większości ich politycy mają mocno konserwatywne poglądy i często sprzeciwiają się liberalnej demokracji oraz tolerancji dla odmienności ${ }^{31}$. Nie bez znaczenia jest również to, iż część tych partii mniej lub bardziej oficjalnie finansowana jest przez podmioty rosyjskie powiązane $\mathrm{z} \mathrm{Kremlem}^{32}$. W ten sposób Rosja chce zbudować sobie sojuszniczy obóz w Europie, który będzie z jednej strony dbał o jej interesy, a z drugiej - destabilizował sytuację wewnętrzną w Unii ${ }^{33}$.

$\mathrm{EP} / / \mathrm{TEXT}+\mathrm{CRE}+20151014+\mathrm{ITEM}-018+\mathrm{DOC}+\mathrm{XML}+\mathrm{V} 0 / / \mathrm{PL} \&$ language $=\mathrm{PL}$ (dostęp: 21.12.205); M. Salvin, J.-L. Schaffhauser, M.-Ch. Arnautu, G. Epitideios, Sytuacja w Syrii (debata), 7.10.2015, http://www.europarl.europa.eu/sides/getDoc.do?pubRef=-//EP//TEXT+CRE+20151007+ITEM$-007+\mathrm{DOC}+\mathrm{XML}+\mathrm{V} 0 / / \mathrm{PL} \&$ language $=\mathrm{PL}$ (dostęp: 30 grudnia 2015).

${ }^{28}$ G. Buonanno, Stan stosunków UE-Rosja, 10.06.2015.

${ }_{29}$ M.-Ch. Arnautu, N. Bay, D. Bilde, G. Buonanno, A. Chauprade, G. Epitideios, B. Kappel, E. Synadinos, Europejska strategia bezpieczeństwa energetycznego, 10.06.2015, http://www.europarl.europa.eu/sides/getDoc.do?pubRef=-//EP//TEXT+CRE+20150610+ITEM-009-06+DOC+XML+V0// PL\&language $=$ PL (dostęp: 22 grudnia 2015).

${ }^{30}$ PVV, op. cit., I. Corrao, Sanzioni Russia: come si matte?, 3.02.2015, http://selezione5stelle. com/sanzioni-russia-come-si-mette/ (dostęp: 10 grudnia 2015); Ttip e la "guerra" contro Putin, per l'Italia un'eutanasia economica, http://www.beppegrillo.it/movimento/parlamento/esteri/2015/01/ ttip-e-la-guerra-contro-putin-per-litalia-uneutanasia-economica.html (dostęp: 11 grudnia 2015).

${ }^{31}$ M. Kokot, Widmo kraży nad Europa, „Gazeta Wyborcza” 2014, nr 125, s. 24-25; J. Rogoża, Korekta państwa Putina: pod szyldem konserwatyzmu, „Analizy OSW”, 2013, http://www.osw. waw.pl/pl/publikacje/analizy/2013-12-18/korekta-panstwa-putina-pod-szyldem-konserwatyzmu (dostęp: 21 grudnia 2015).

${ }^{32}$ MW, „Sunday Telegraph”: Amerykanie oskarżaja Rosję o finansowanie partii w Europie, „Gazeta Wyborcza” 2016, nr ?, http://wyborcza.pl/1,75477,19490861,sunday-telegraph-amerykanie-oskarzaja-rosje-o-finansowanie.html\#ixzz3ykgopgL8 (dostęp: 29 stycznia 2016); J. Lichfield, Marine Le Pen battered by controversy as details emerge of hacked Kremlin text messages and holocaust-minimising from her father; , „Independent” 2016, nr?, http://www.independent.co.uk/news/ world/europe/marine-le-pen-battered-by-controversy-as-details-emerge-of-hacked-kremlin-textmessages-and-holocaustminimising-from-her-father-10154589.html (dostęp: 24 stycznia 2016); D. Bauwens, Drie Vlaams Belangers zonder mandaat van de partij naar de Krim, http://deredactie. be/cm/vrtnieuws/buitenland/1.1909292 (dostęp: 23 stycznia 2016).

${ }^{33}$ J. Rogoża, Kreml „zagospodarowuje” europejskq skrajną prawice, http://www.osw.waw.pl/ pl/publikacje/analizy/2015-03-25/kreml-zagospodarowuje-europejska-skrajna-prawice (dostęp: 25 stycznia 2016). 
Wspomniana wyżej niechęć do Stanów Zjednoczonych połączona $\mathrm{z}$ dążeniem do zacieśniania współpracy z Rosją powoduje, że zdecydowana większość analizowanych partii eurosceptycznych chce ograniczenia roli NATO, a nawet jego rozwiązania. Według nich Sojusz Północnoatlantycki jest reliktem zimnej wojny, a obecnie stał się instrumentem, za pomocą którego Stany Zjednoczone kontrolują Europę i realizują swoje interesy ${ }^{34}$. Potwierdzeniem tej tezy, według eurosceptyków, jest to, że Waszyngton wykorzystuje NATO do prowokowania Rosji, rozszerzając Sojusz - wbrew złożonym w latach dziewięćdziesiątych XX w. zobowiązaniom - na wschód kontynentu, ale także poprzez manewry wojskowe i czasową relokację wojsk ${ }^{35}$. Dlatego część partii eurosceptycznych uważa, iż należy rozwiązać struktury europejskie NATO i zbudować nowy sojusz obronny w oparciu o współpracę z Rosją. Wyjątek w tym gronie stanowią brytyjski UKIP, holenderska Partia Wolności i duńska Partia Ludowa, które widzą w Pakcie Północnoatlantyckim instrument zabezpieczający zaangażowanie Stanów Zjednoczonych w Europie ${ }^{36}$.

Ostatnim wspólnym obszarem zainteresowania tych partii jest napływ nielegalnych imigrantów do Europy. Kwestia ta w ostatnim czasie stała się jednym z najważniejszych problemów Europy, o charakterze zarówno wewnętrznym, jak i międzynarodowym. Partie te krytykują bezsilność rządów państw członkowskich i działania podejmowane w ramach Unii Europejskiej. Co oczywiste, zdecydowanie sprzeciwiają się przyjmowaniu imigrantów i uchodźców z Afryki Północnej i Bliskiego Wschodu ${ }^{37}$. Odrzucają jednak możliwość interwencji zbrojnej na Bliskim Wschodzie, wskazując, iż druga wojna w Iraku oraz interwencja zachodnia w Libii nie przyniosły oczekiwanych rezultatów, pogłębiając przy tym problemy regionu. Część eurosceptyków uważa jednak, że państwa członkowskie powinny użyć swoich sił zbrojnych do zatamowania napływu nielegalnych imigrantów, np. blokując nimi statki, odholowując je z powrotem tam, skąd wypłynęły, czy niszcząc infrastrukturę wykorzystywaną przez przemytników ${ }^{38}$.

\section{Obszary współpracy w ramach zjednoczonej Europy}

Wspomniane powyżej obszary łączące partie eurosceptyczne są objawem pewnej wspólnoty poglądów, nieprzełożonej jednak na założenia programowe żad-

${ }^{34}$ Le Pen says...; Vilimsky: Rolle...; J. Korwin-Mikke, Sytuacja na Ukrainie...; Ucraina, ammissioni Biden...; U. Voigt, H. Vilimsky, Sytuacja na Ukrainie, 15.07.2014; M. Červenka, Mediální matrix má povážlivé trhliny, https://web.svobodni.cz/clanky/miroslav-cervenka-medialni-matrix-ma-povazlive-trhliny (dostęp: 16 grudnia 2015).

${ }^{35}$ M. Ciastoch, op. cit.; M. Červenka, op. cit.; Z. Balczó, Sytuacja na Ukrainie (debata), 14.10.2015; G. Annemans, Stan stosunków UE -Rosja, 10.06.2015.

${ }^{36}$ Y. Ben-Hur Levy, op. cit., s. 5.

${ }^{37}$ Jedynie UKIP dopuszcza przyjęcie bliskowschodnich chrześcijan.

${ }^{38}$ M. de Graaff, Sytuacja w Syrii... 
nej z dwóch wspomnianych grup europarlamentarnych. Ich wspólną cechą jest to, że koncentrują się przede wszystkim na roli poszczególnych państw, a nie na Unii Europejskiej jako takiej. Nie oznacza to jednak, iż członkowie ugrupowań eurosceptycznych nie dopuszczają w żadnym wymiarze aktywności międzynarodowej zjednoczonej Europy. W pewnych obszarach widzą oni pewną wartość dodaną w tym, że istnieje organizacja pozwalająca państwom europejskim występować wspólnie na arenie międzynarodowej. Można wyróżnić dwa główne obszary współpracy pojawiające się $\mathrm{w}$ wypowiedziach przedstawicieli partii eurosceptycznych, którymi mogłaby zajmować się Unia nawet po radykalnym ograniczeniu jej kompetencji.

Pierwszym z nich jest współpraca rozwojowa, która traktowana jest przez wiele ugrupowań eurosceptycznych jako skuteczny instrument ograniczenia imigracji do Europy. Istnieje świadomość, że bez poprawy sytuacji społeczno-gospodarczej i politycznej w krajach pochodzenia nielegalnych imigrantów nie ma możliwości całkowitego powstrzymania napływu ich do Europy ${ }^{39}$. Dlatego według wielu członków partii eurosceptycznych skuteczniejsza jest pomoc w krajach pochodzenia migrantów niż odgradzanie się Starego Kontynentu od reszty świata. Znaczna część z nich uważa, iż Unia i rządy narodowe wydają nieefektywnie środki finansowe na współpracę rozwojową, co nie oznacza jednak, iż nie akceptują tej polityki w ogóle ${ }^{40}$. Przede wszystkim podkreślają oni, że zależy im na bardziej efektywnym i racjonalnym wydawaniu pieniędzy, co niewątpliwie jest próbą zastosowania logiki perswazji. Uważają, że obecny sposób prowadzenia polityki wsparcia rozwojowego - a przede wszystkim niemal całkowity brak kontroli nad nią — sprawia, że są one marnotrawione oraz rozkradane przez skorumpowane reżimy. Natomiast podniesienie efektywności umożliwi ograniczenie wydatków na pomoc rozwojową, a tym samym zmniejszenie obciążeń europejskich podatników, co jest istotną wartością dla części tych ugrupowann ${ }^{41}$. Być może więc mamy w tym wypadku do czynienia $\mathrm{z}$ zastosowaniem modelu cyklu życia normy ${ }^{42}$, w ramach którego

${ }^{39}$ L'écologie au cour du développement, http://www.frontnational.com/le-projet-de-marine-le-pen/avenir-de-la-nation/ecologie-securite-alimentaire-et-industrielle-protection-animale/ (dostęp: 30 stycznia 2016); Ansa, Lega Nord, il nigeriano Toni Iwobi responsabile per l'immigrazione. Matteo Salvini: „Non è operazione ipocrita”, „L'Huffington Post”, 1.10.2014, http://www.huffingtonpost.it/2014/10/01/lega-nord-nigeriano_n_5915572.html (dostęp: 21 stycznia 2016); Immigrati, la lega presenta il progetto-nigeria. Iwobi nella capitale, http://www.leganord.org/index.php/notizie/le-news/13770-immigrati-la-lega-presenta-il-progetto-nigeria-iwobi-nella-capitale (dostęp: 21 stycznia 2016); L. Aliot, UE i globalne ramy rozwoju po roku 2015, 24.11.2014, http://www.europarl.europa.eu/sides/getDoc.do?type $=$ CRE\&reference $=20141124 \&$ secondRef=ITEM-016\&langua ge=PL\&ring=A8-2014-0037 (dostęp: 21 stycznia 2016).

${ }^{40}$ Istotnym wyjątkiem jest tutaj holenderska Partia Wolności, która w ogóle kwestionuje sens polityki wsparcia rozwojowego; Wat wil de PVV?, http://geertwilders.webklik.nl/page/standpunten (dostęp: 21 stycznia 2016).

${ }^{41}$ Rebuild Prosperity, http://www.ukip.org/issues (dostęp: 6 stycznia 2016); Wat wil...

${ }^{42} \mathrm{~J}$. Czaputowicz, Wprowadzenie. Potencjał konstruktywizmu w wyjaśnieniu integracji europejskiej, [w:] Zastosowanie konstruktywizmu w studiach europejskich, red. J. Czaputowicz, Warszawa 2016, s. 23. 
przez odwołanie się do podzielanych przez drugą stronę argumentów próbuje się doprowadzić do „kaskadowania normy” i przekonania oponentów do swoich racji - w tym przypadku sprowadzających się do ograniczenia wydatków na politykę wsparcia rozwojowego.

Drugim obszarem współpracy, w którym omawiane partie dopuściłyby pewną aktywność Unii Europejskiej, jest polityka klimatyczna. Wynika to z faktu, iż część partii eurosceptycznych prezentuje w mniejszym lub większym stopniu proekologiczne nastawienie. Nie negują one zmian klimatycznych oraz tego, iż ich źródłem jest aktywność człowieka (wyjątkiem jest brytyjski UKIP ${ }^{43}$ oraz polski $\mathrm{KORWiN}^{44}$ ). Konsekwencją tego myślenia jest założenie, iż w celu ograniczenia negatywnych zmian klimatycznych konieczne są określone działania podejmowane przez całą społeczność międzynarodową ${ }^{45}$. Aktywność w tym obszarze wyłącznie części państw europejskich, a nawet całej Europy, nie będzie skuteczna, jeżeli nie przyłączą się do nich inni emitenci gazów cieplarnianych. Dlatego też eurosceptyczni politycy nie tyle doceniają, ile akceptują rolę odgrywaną przez Unię Europejską w tym obszarze. Unia jest dla nich w tym wypadku raczej forum uzgadniania wspólnego europejskiego stanowiska i prezentowania go na zewnątrz, a także swoistego rodzaju instrumentem nacisku na pozostałych aktorów międzynarodowych $^{46}$. Widać to było bardzo wyraźnie w czasie dyskusji nad rezultatami szczytu klimatycznego w Paryżu, kiedy to część eurosceptycznych polityków zarzucała Brukseli, iż nie była w stanie wymusić wiążących zobowiązań ${ }^{47}$. Ta ograniczona akceptacja unijnej polityki klimatycznej nie oznacza, iż partie eurosceptycznie nie krytykują Brukseli. Przede wszystkim - podobnie jak przy współpracy rozwo-

${ }^{43}$ UKIP Manifesto 2014, Create an earthquake, s. 7, http://d3n8a8pro7vhmx.cloudfront.net/ themes/5308a93901925b5b09000002/attachments/original/1398869254/EuroManifestoLaunch. pdf?1398869254 (dostęp: 22 stycznia 2016); R. Helmer, Europe feeling the cost of climate change policy, „The Parliament Magazine. Politics, Policy and People”, 8.12.2014, https://www.theparliamentmagazine.eu/articles/feature/europe-feeling-cost-climate-change-policy (dostęp: 21 stycznia 2016); J. Reid, Wyniki COP 21 (debata), 15.12.2015, http://www.europarl.europa.eu/sides/getDoc.do?pubRef=-//EP//TEXT+CRE+20151215+ITEM-009+DOC+XML+V0//PL\&language=PL (dostęp: 30 stycznia 2016).

${ }^{44}$ R. Iwaszkiewicz, Plan działania na rzecz nowego międzynarodowego porozumienia $w$ sprawie klimatu, które ma zostać przyjęte w Paryżu, 28.01.2015, http://www.europarl.europa.eu/sides/ getDoc.do?pubRef=-//EP//TEXT+CRE+20150128+ITEM-014+DOC+XML+V0//PL\&language=PL (dostęp: 22 stycznia 2016); J. Korwin-Mikke, Konferencja ONZ w sprawie zmiany klimatu w 2014 r. - COP 20 w Limie, Peru, 26.11.2014, http://www.europarl.europa.eu/sides/getDoc.do?pubRef=-// $\mathrm{EP} / / \mathrm{TEXT}+\mathrm{CRE}+20141126+\mathrm{ITEM}-007+\mathrm{DOC}+\mathrm{XML}+\mathrm{V} 0 / / \mathrm{PL} \&$ language=PL (dostęp: 18 stycznia 2016).

${ }^{45}$ Clima: Lima non sia una passerella politica, ma terreno fertile per gli obiettivi di riduzione di CO2 e rilancio dell'occupazione verde, 03.12.2014, http://www.beppegrillo.it/movimento/parlamento/attivitaproduttive/2014/12/clima-lima-non-sia-una-passerella-politica-ma-terreno-fertile-per-gli-obiettivi-di-riduzione-di-co2.html (dostęp: 16 stycznia 2015).

${ }^{46}$ Környezetvédelmi program, http://jobbik.hu/programunk/kornyezetvedelem (dostęp: 17 stycznia 2015).

${ }^{47}$ S. Briois, L. Fountoulis, Wyniki COP 21... 
jowej - zarzuty sprowadzają się do jej małej skuteczności. Politycy omawianych ugrupowań wskazują bardzo często, iż Unia i jej państwa członkowskie nie są w stanie przekonać innych emitentów do przyjęcia na siebie zobowiązań redukcyjnych. A to sprawia, iż Europa traci na konkurencyjności w globalnej gospodar$\mathrm{ce}^{48}$. Tak więc argumenty części partii eurosceptycznych sprowadzają się raczej do nieskuteczności polityki klimatycznej - w sensie niemożności przekonania partnerów do równie zaangażowanej postawy, a nie do jej bezcelowości ${ }^{49}$. Wydaje się, że zrozumienie części tych partii dla polityki klimatycznej wynika w znacznej mierze z proekologicznego nastawienia społeczeństw państw członkowskich. To, że są one wyczulone na kwestie ochrony środowiska, powoduje, iż politycy eurosceptyczni - bardzo często populistyczni - muszą wpisywać się w te nastroje. Mamy więc tutaj do czynienia $\mathrm{z}$ wystąpieniem logiki stosowności, która nakazuje zachowywać się w określony - społecznie oczekiwany - sposób. Dlatego też widać wyraźny podział pomiędzy partiami eurosceptycznymi. W tych krajach, gdzie kwestie ekologiczne nie odgrywają ważnej roli, partie eurosceptyczne uważają unijną politykę klimatyczną za aberrację. Tam, gdzie kwestie ekologiczne są istotne dla społeczeństwa - wykazują dla niej zrozumienie.

W tych dwóch obszarach można więc zauważyć pewne odejście niektórych z omawianych partii od twardego eurosceptycyzmu, a więc porzucenie roli, którą odgrywają zarówno na arenie krajowej, jak i forum Parlamentu Europejskiego. Kierując się racjonalnymi przesłankami, uważają one, iż Unia - oczywiście bardzo mocno ograniczona w swoich kompetencjach — może być bardzo wygodnym forum uzgadniania i prezentowania wspólnego stanowiska na arenie międzynarodowej. W kwestiach polityki współpracy rozwojowej i polityki klimatycznej można odnaleźć pewną paneuropejską wspólnotę interesów, która - po to, aby była skutecznie realizowana na arenie międzynarodowej - wymaga współpracy i połączenia zasobów. Tylko w ten sposób będzie możliwe zabezpieczenie interesów państw europejskich. Można więc w tym przypadku dostrzec pewną istotną ewolucję tożsamości zachodzącą w ramach analizowanych ugrupowań. Być może jest ona wynikiem zaistnienia logiki stosowności, która wymusiła dostosowanie się do poglądów społecznych dominujących w poszczególnych państwach członkowskich. Nie jest jednak wykluczone, iż w tym przypadku zachodzi wspomniany już tzw. cykl życia normy, a eurosceptyczni politycy przez stosowanie logiki perswazji próbują oddziaływać na dominujące poglądy ${ }^{50}$.

${ }^{48}$ Z. Balczó, R. Helmer, O. Stuger, Wyniki COP 21...; Z. Balczó, COP 21 (debata), 20.01.2016, http://www.europarl.europa.eu/sides/getDoc.do?pubRef=-//EP//TEXT+CRE+20160120+ITEM011+DOC+XML+V0//PL\&language $=\mathrm{PL}$ (dostęp: 30 stycznia 2016).

${ }^{49}$ Z. Balczó, G. Lebreton, F. Obermayr, Konferencja ONZ...; Z. Balczó, Plan działania...

${ }^{50}$ Szerzej na ten temat F. Tereszkiewicz, Konstruktywizm jako perspektywa badawcza zachowań eurosceptyków w Parlamencie Europejskim w obszarze unijnych działań zewnętrznych, „Studia Europejskie", w druku. 


\section{Wspólnota, która marzy się eurosceptykom}

Przeprowadzona powyżej analiza pokazała, że w ramach badanych ugrupowań eurosceptycznych można wyodrębnić wspólne dla nich tzw. dyskursywne punkty węzłowe dotyczące miejsca zjednoczonej Europy w globalnym układzie sił. Umożliwia to stworzenie pewnego modelu wspólnoty europejskiej opartej na eurosceptycznej tożsamości międzynarodowej - a więc wspólnej wizji tego, jakie ma być miejsce zredukowanej Unii albo Europy państw narodowych w środowisku międzynarodowym. Fundamentem tej wizji jest znaczne ograniczenie oczywiście, jeżeli nadal będzie istniała - roli Unii Europejskiej, w tym przede wszystkim jej instytucji ponadnarodowych. Partie te byłyby w stanie zaakceptować dalsze funkcjonowanie instytucji o charakterze międzyrządowym, takich jak Rada Europejska i Rada, ale sprowadzonych jedynie do forów, na których wypracowywane byłyby decyzje na zasadzie konsensusu i to tylko w tych obszarach, gdzie państwa członkowskie miałyby wspólne interesy, a osiągnięcie celu wymagałoby wspólnej aktywności międzynarodowej. Takimi obszarami z pewnością były polityka klimatyczna i polityka współpracy rozwojowej, ale lista ta byłaby kształtowana ad hoc. We wszystkich tych kwestiach zjednoczona Europa powinna jednak przestać odgrywać rolę samotnego lidera, a zacząć forsować swoje interesy oraz skuteczniej nakłaniać partnerów do współpracy.

Po drugie, „wspólnota europejska” w swojej aktywności zewnętrznej powinna być zjednoczona $\mathrm{w}$ konfrontacji $\mathrm{z}$ islamem, który stanowi obecnie największe wyzwanie dla europejskiego systemu wartości, systemu socjalnego państw członkowskich oraz - poprzez terroryzm i drobną przestępczość - dla ich bezpieczeństwa wewnętrznego. Ta konfrontacja ze światem muzułmańskim wymusza na państwach członkowskich ściślejszą współpracę z Moskwą. Bez rosyjskiego zaangażowania nie uda się bowiem ustabilizować Bliskiego Wschodu oraz Afryki Północnej, a tym samym ochronić kontynentu przed kolejną falą uchodźców. Poza tym Rosja umożliwi zmniejszenie zależności energetycznej od państw muzułmańskich, jak również pozbawi ich europejskich pieniędzy, za które propagują radykalną wersję islamu. To wszystko sprawia, że głównym sojusznikiem zintegrowanej Europy, według eurosceptyków, powinna być Rosja, co wymusza respektowanie jej prawa do wpływania na sytuację w strefie postradzieckiej (np. na Ukrainie). Sojusz z Moskwą powinien mieć wielowymiarowy charakter i nie ograniczać się wyłącznie do kwestii gospodarczych czy politycznych. Państwa europejskie i Rosja mają współpracować ze sobą w ochronie podstawowych wartości cywilizacji europejskiej, które są zagrożone rozprzestrzeniającym się islamem.

Połączona sojuszem z Moskwą „wspólnota europejska” powinna budować swoją tożsamość nie tylko w konfrontacji ze światem muzułmańskim, lecz także w opozycji do Stanów Zjednoczonych. Interes państw europejskich wymusza na nich prowadzenie bardziej asertywnej polityki w stosunku do tego kraju, co bę- 
dzie oznaczało odrzucenie umów liberalizujących wymianę handlową i odejście od anglosaskiego modelu kapitalizmu. Osłabienie relacji z USA będzie również oznaczało rozwiązanie NATO i konieczność zbudowania sojuszu obronnego w ramach Europy i najlepiej we współpracy z Rosją.

\section{Zakończenie}

Powyższa analiza bardzo wyraźnie pokazuje, że podstawowe założenia nowej „wspólnoty europejskiej” budowane są w konfrontacji z dotychczasowym modelem i oparte są na paneuropejskiej wizji sojuszu z Rosją. Ma ona niewątpliwie cechy wspólnoty bezpieczeństwa, której członkowie według E. Adlera i M. Barnetta muszą dzielić wspólne tożsamości, wartości i pojęcia oraz kierować się w swoich działaniach poczuciem odpowiedzialności za nią. Analizując dyskurs eurosceptyczny dotyczący działań zewnętrznych Unii, można dostrzec bardzo wyraźnie, iż występuje w nim pewien wspólny system wartości, swojego rodzaju europejski styl życia, który w wypowiedziach eurosceptycznych polityków przeciwstawiany jest modelowi amerykańskiemu i muzułmańskiemu. Można również zauważyć pewnego rodzaju poczucie odpowiedzialności za przyszłość w takiej lub innej formie zjednoczonej Europy. Zaznaczyć jednak trzeba, iż nie wszystkie założenia tej wspólnoty są w jednakowy sposób akceptowane przez analizowane partie eurosceptyczne. Część z nich - przede wszystkim UKIP oraz holenderska Partia Wolności - odrzuca niektóre jej elementy. Jednak, jeżeli prześledzi się wypowiedzi liderów politycznych pozostałych ugrupowań i przeanalizuje dokumenty programowe, to bardzo wyraźnie widać wspólną narrację, w której przebija się niechęć do Unii, islamu i USA, a także swoista fascynacja Rosją. Może to oznaczać, że działania podejmowane przez Kreml przynoszą oczekiwany skutek i tworzy się w Europie środowisko polityczne bardzo mocno mu przychylne albo też władze Rosji bardzo dobrze zdefiniowały swój cel aktywności, uznając, iż dużo łatwiej będzie przekonać do swoich racji środowiska eurosceptyczne niż - wydawałoby się bliższe im historycznie - ugrupowania radykalnie lewicowe. Niezależnie jednak od tego, jakie jest podłoże tego procesu, widać, że wśród eurosceptyków rysuje się pewna alternatywna wizja „wspólnoty europejskiej” — opartej na swego rodzaju eurosceptycznej tożsamości europejskiej - czerpiącej jednak w niektórych kwestiach z dorobku istniejącej Unii.

\section{Bibliografia}

Adler E., Barnett M., A framework for the study of security communities, [w:] Security Communities, red. E. Adler, M. Barnett, Cambridge 1998.

Ansa, Lega Nord, il nigeriano Toni Iwobi responsabile per l” immigrazione. Matteo Salvini: „Nonè operazione ipocrita”, „L'Huffington Post”, 1.10.2014, http://www.huffingtonpost.it/2014/10/01/lega-nord-nigeriano_n_5915572.html. 
Bauwens D., Drie Vlaams Belangers zonder mandaat van de partij naar de Krim, http://deredactie. $\mathrm{be} / \mathrm{cm} / \mathrm{vrtnieuws} /$ buitenland/1.1909292.

Ben-Hur Levy Y., The Undiplomats: Right-wing populist and their foreign policies, 2015, http:// www.cer.org.uk/sites/default/files/publications/attachments/pdf/2015/pb_ybl_undiplo_21aug15-11804.pdf.

Bermingham F., Rochester By-Election: What's Ukip's Policy on TTIP?, „International Business Times", 21.11.2014, http://www.ibtimes.co.uk/rochester-by-election-whats-ukips-policy-ttip1475884.

Ciastoch M., Korwin-Mikke: To Amerykanie zdestabilizowali Ukrainę, http://swiat.newsweek.pl/ janusz-korwin-mikke-teorie-spiskowe-ameryka-chce-oslabic-rosje,artykuly,359188,1.html.

Clima: Lima non sia una passerella politica, ma terreno fertile per gli obiettivi di riduzione di CO2 e rilancio dell'occupazione verde, 03.12.2014, http://www.beppegrillo.it/movimento/parlamento/attivitaproduttive/2014/12/clima-lima-non-sia-una-passerella-politica-ma-terreno-fertile-per-gli-obiettivi-di-riduzione-di-co2.html.

COP 21 (debata), 20.01.2016, http://www.europarl.europa.eu/sides/getDoc.do?pubRef=-//EP// TEXT+CRE+20160120+ITEM-011+DOC+XML+V0//PL\&language=PL.

Corrao I., Sanzioni Russia: come si matte?, 3.02.2015, http://selezione5stelle.com/sanzioni-russia-come-si-mette/.

Červenka M., Mediální matrix má povážlivé trhliny, https://web.svobodni.cz/clanky/miroslav-cervenka-medialni-matrix-ma-povazlive-trhliny.

Czaputowicz J., Wprowadzenie. Potencjał konstruktywizmu w wyjaśnieniu integracji europejskiej, [w:] Zastosowanie konstruktywizmu w studiach europejskich, red. J. Czaputowicz, Warszawa 2016.

Deklaracja praska, http://www.ecrg.pl/pl/o_nas/.

Diez Th., The Economic Community Reading of Europe: Its Discursive Nodal Points and Ambiguities Towards „Westphalia”, “Working Papers” 1998, nr 6.

Diez Th., Europe as a Discursive Battleground. Discourse Analysis and European Integration Studies, "Cooperation and Conflict" 2001, nr 1(36).

Europejska strategia bezpieczeństwa energetycznego, 10.06.2015, http://www.europarl.europa.eu/ sides/getDoc.do?pubRef=-//EP//TEXT+CRE+20150610+ITEM-009-06+DOC+XML+V0// PL\&language $=$ PL.

Grupa Europa Narodów i Wolności, http://www.europarl.europa.eu/meps/pl/search.html?politicalGroup $=4907$.

Helmer R., Europe feeling the cost of climate change policy, „The Parliament Magazine. Politics, Policy and People", 8.12.2014, https://www.theparliamentmagazine.eu/articles/feature/europe-feeling-cost-climate-change-policy.

Immigrati, la lega presenta il progetto-nigeria. Iwobi nella capitale, http://www.leganord.org/index. $\mathrm{php} /$ notizie/le-news/13770-immigrati-la-lega-presenta-il-progetto-nigeria-iwobi-nella-capitale.

Ivanauskas J., Rolandas Paksas: „Apsimesdami didžiais valstybès gynejjais, kai kurie "patriotai" daro viską, kad bütu išprovokuotas karinis konfliktas su Rusija!”, http://www.laisvaslaikrastis. lt/news/2482/53/d,detalus/.

Kokot M., Widmo krąży nad Europa, „Gazeta Wyborcza” 2014, nr 125.

Konferencja ONZ w sprawie zmiany klimatu w 2014 r. - COP 20 w Limie, Peru, 26.11.2014, http:// www.europarl.europa.eu/sides/getDoc.do?pubRef=-//EP//TEXT+CRE+20141126+ITEM$-007+\mathrm{DOC}+\mathrm{XML}+\mathrm{V} 0 / / \mathrm{PL} \&$ language $=\mathrm{PL}$.

Korwin-Mikke J. w audycji Wybierz swojego prezydenta w radiu TOK FM, https://www.youtube. $\mathrm{com} /$ watch?v=F8GTH4G2E2w\&index=15\&list=PLVLI1ArZ-BLZv4sLKp_nmH_Ml6cF4AzIW.

Környezetvédelmi program, http://jobbik.hu/programunk/kornyezetvedelem.

Leconte C., From Pathology to mainstream phenomenon: Reviewing the Euroscepticism debate in research and theory, „International Political Science Review” 2015, 36. 
L'écologie au cour du développement, http://www.frontnational.com/le-projet-de-marine-le-pen/ avenir-de-la-nation/ecologie-securite-alimentaire-et-industrielle-protection-animale/.

Le Pen says Washington attempting to start 'war in Europe', http://rt.com/news/230503-le-pen-uslackey/.

Lichfield J., Marine Le Pen battered by controversy as details emerge of hacked Kremlin text messages and holocaust-minimising from her father, „Independent” 2016, $\mathrm{nr}$ ?, http://www.independent.co.uk/news/world/europe/marine-le-pen-battered-by-controversy-as-details-emerge-ofhacked-kremlin-text-messages-and-holocaustminimising-from-her-father-10154589.html.

Macro-financial assistance to Ukraine, http://www.votewatch.eu/en/term8-macro-financial-assistance-to-ukraine-draft-legislative-resolution-vote-legislative-resolution-ordin.html\#/.

Members, http://www.efdgroup.eu/our-meps/members.

MW, „Sunday Telegraph”: Amerykanie oskarżają Rosję o finansowanie partii w Europie, „Gazeta Wyborcza” 2016, nr ?, http://wyborcza.pl/1,75477,19490861,sunday-telegraph-amerykanie-oskarzaja-rosje-o-finansowanie.html\#ixzz3ykgopgL8.

Moroska A., Prawicowy populizm i eurosceptycyzm (na przykładzie Listy Pima Fortuyna w Holandii i Ligii Polskich Rodzin w Polsce), Wrocław 2010.

Negocjacje $w$ sprawie transatlantyckiego partnerstwa handlowo-inwestycyjnego (TTIP), 9.07.2015, http://www.europarl.europa.eu/sides/getDoc.do?pubRef=-//EP//TEXT+CRE+20150709 + ITEM-013-01+DOC+XML+V0//PL\&language $=$ PL.

Nuttall P., UKIP statement on TTIP, 15.10.2015, http://www.paulnuttallmep.com/ukip-statementon-ttip/.

Nya diskussioner om SD:s Putin-relation efter DN:s avslöjande, https://eublogg.wordpress. com/2015/02/16/nya-diskussioner-om-sds-putin-relation-efter-dns-avslojande/.

Plan działania na rzecz nowego międzynarodowego porozumienia w sprawie klimatu, które ma zostać przyjęte w Paryżu, 28.01.2015, http://www.europarl.europa.eu/sides/getDoc.do?pubRef=-// $\mathrm{EP} / / \mathrm{TEXT}+\mathrm{CRE}+20150128+\mathrm{ITEM}-014+\mathrm{DOC}+\mathrm{XML}+\mathrm{V} 0 / / \mathrm{PL} \&$ language $=\mathrm{PL}$.

PVV, Welk belang heeft de Nederlander bij sancties tegen Rusland?, http://www.pvv.nl/index. $\mathrm{php} / 37$-fj-related/raymond-de-roon/7463-pvv-welk-belang-heeft-de-nederlander-bij-sanctiestegen-rusland.html.

Rebuild Prosperity, http://www.ukip.org/issues.

Rogoża J., Korekta państwa Putina: pod szyldem konserwatyzmu, „Analizy OSW”, 2013, http:// www.osw.waw.pl/pl/publikacje/analizy/2013-12-18/korekta-panstwa-putina-pod-szyldem-konserwatyzmu.

Rogoża J., Kreml „zagospodarowuje” europejską skrajną prawicę, http://www.osw.waw.pl/pl/publikacje/analizy/2015-03-25/kreml-zagospodarowuje-europejska-skrajna-prawice.

Russia-index: 11 new EU-sceptic parties added, https://eublogg.wordpress.com/2015/01/10/russiaindex-11-new-eu-sceptic-parties-added/.

Smith N., UKIP's Policy on the NHS and TTIP's, 25.01.2015, http://lincolngainsboro.blogspot. com/2015/01/ukips-policy-on-nhs-and-ttips.html.

Sørensen C., Love me, love me not... A typology of public Euroscepticism, „SEI Working Paper” 2008, nr 101.

Stan stosunków UE-Rosja, 10.06.20 15, http://www.europarl.europa.eu/sides/getDoc.do?pubRef=-// $\mathrm{EP} / / \mathrm{TEXT}+\mathrm{CRE}+20150610+\mathrm{ITEM}-009-05+\mathrm{DOC}+\mathrm{XML}+\mathrm{V0} / / \mathrm{PL} \&$ language=PL.

Sytuacja na Ukrainie, 15.07.2014, http://www.europarl.europa.eu/sides/getDoc.do?pubRef=-//EP// TEXT+CRE+20140715+ITEM-008+DOC+XML+V0//PL\&language $=$ PL.

Sytuacja na Ukrainie (debata), 14.10.2015, http://www.europarl.europa.eu/sides/getDoc.do?pubRef $=-/ / \mathrm{EP} / / \mathrm{TEXT}+\mathrm{CRE}+20151014+\mathrm{ITEM}-018+\mathrm{DOC}+\mathrm{XML}+\mathrm{V} 0 / / \mathrm{PL} \&$ language $=\mathrm{PL}$.

Sytuacja na Ukrainie i stan stosunków UE-Rosja, 16.09.2014, http://www.europarl.europa.eu/sides /getDoc.do?pubRef=-//EP//TEXT+CRE+20140916+ITEM-004+DOC+XML+V0//PL\&langua$\mathrm{ge}=\mathrm{PL}$. 
Sytuacja $w$ Syrii (debata), 7.10.2015, http://www.europarl.europa.eu/sides/getDoc.do?pubRef=-// $\mathrm{EP} / / \mathrm{TEXT}+\mathrm{CRE}+20151007+\mathrm{ITEM}-007+\mathrm{DOC}+\mathrm{XML}+\mathrm{V} 0 / / \mathrm{PL}$ \&language $=\mathrm{PL}$.

Szczerbiak A., Taggart P., Theorising party-based Euroscepticism: Problems of definition, measurement and causality, „SEI Working Paper”, 2003, nr 69.

Tereszkiewicz F., Unia Eurosceptyków - implikacje dla działań zewnętrznych Unii Europejskiej, [w:] Integracja europejska. Główne obszary badawcze, red. K.A. Wojtaszczyk, J. Tymanowski, P. Stawarz, Warszawa 2015.

Ttip e la „guerra" contro Putin, per l'Italia un'eutanasia economica, http://www.beppegrillo.it/movimento/parlamento/esteri/2015/01/ttip-e-la-guerra-contro-putin-per-litalia-uneutanasia-economica.html.

Transatlantyckie Partnerstwo $w$ dziedzinie Handlu i Inwestycji (TTIP), 15.07.2014, http://www.europarl.europa.eu/portal/pl, http://www.europarl.europa.eu/sides/getDoc.do?pubRef=-//EP// TEXT+CRE+20140715+ITEM-009+DOC+XML+V0//PL\&language $=$ PL.

Ucraina, ammissioni Biden, Pini (ln): Mogherini mente, sanzioni a Russia pilotate da usa, http://leganord.org/index.php/notizie/le-news/13287-ucraina-ammissioni-biden-pini-ln-mogherini-mente-sanzioni-a-russia-pilotate-da-usa.

UE $i$ globalne ramy rozwoju po roku 2015, 24.11.2014, http://www.europarl.europa.eu/sides/ getDoc.do? type $=$ CRE $\&$ reference $=20141124 \&$ second Ref $=$ ITEM-016\&language $=$ PL\&ring $=$ A8-2014-0037.

UKIP Manifesto 2014, Create an earthquake, http://d3n8a8pro7vhmx.cloudfront.net/themes/ 5308a93901925b5b09000002/attachments/original/1398869254/EuroManifestoLaunch. pdf?1398869254.

Vasilopolou S., Varieties of Euroscepticism: The case of the European extreme right, „Journal of Contemporary European Research" 5, 2009.

Vilimsky: Rolle der NATO in der Ukraine bedenklich, http://www.ots.at/presseaussendung/ OTS_20150311_OTS0168/vilimsky-rolle-der-nato-in-der-ukraine-bedenklich.

Wat wil de PVV?, http://geertwilders.webklik.nl/page/standpunten.

Wyniki COP 21 (debata), 15.12.2015, http://www.europarl.europa.eu/sides/getDoc.do?pubRef=-// $\mathrm{EP} / / \mathrm{TEXT}+\mathrm{CRE}+20151215+\mathrm{ITEM}-009+\mathrm{DOC}+\mathrm{XML}+\mathrm{V} 0 / / \mathrm{PL} \&$ language $=\mathrm{PL}$.

Zuba K., Polski eurosceptycyzm i eurorealizm, Opole 2006. 